\title{
水位低下による土砂スルーシング時の 超音波を用いたSS 濃度と粒度分布の連続計測 \\ MEASUREMENT OF SUSPENDED SEDIMENT CONCENTRATION AND PARTICLE SIZE DISTRIBUTION USING ULTRASOUND DURING SEDIMENT SLUICING BY DRAWDOWN OPERATION
}

\author{
古川仁志 $1 \cdot$ 前田修一 $2 \cdot$ 猪股重光 $^{3} \cdot$ 田井秀一 $4 \cdot$ 小林力 5 \\ Hitoshi FURUKAWA, Syu-ichi MAEDA, Shigemitsu INOMATA, Hidekazu TAI and Tsutomu \\ KOBAYASHI \\ 1 正会員＼cjkstart電源開発株式会社土木建築部（†104-8165 東京都中央区銀座六丁目 15-1） \\ 2 正会員 電源開発株式会社中部支店土木グループ 課長（†486-0815 愛知県春日井市十三塚町 1-43） \\ 3 非会員 北斗理研株式会社 開発部長（†189-0026 東京都東村山市多摩湖町 1-25-2） \\ 4 非会員 博 (工) 日本大学准教授 工学部電気電子工学科（广963-8642 福島県郡山市田村町徳定） \\ 5 非会員 工博 日本大学名誉教授 工学部電気電子工学科（同上）
}

\begin{abstract}
In recent years, ultrasonic attenuation spectroscopy has been frequently used for the measurement of suspended sediment concentration and particle size distribution. Sediments are derived from the rock masses at the upper basin and transported downstream owing to floods, and then deposited in the reservoir. The reservoir sediments affect the entire river system because the sediment transport is blocked by dams. For this reason, sediment sluicing has been performed in several rivers. In such cases, it is important to monitor the suspended sediment concentration and particle size distribution. Therefore, we have measured the suspended sediment concentration and particle size distribution using an ultrasonic spectrometer during sediment sluicing by drawdown operation. The applicability of our measurement technology using ultrasonic attenuation spectroscopy for monitoring of suspended sediment concentration and particle size distribution was verified.
\end{abstract}

Key Words : Sediment sluicing, concentration, particle size distribution, ultrasonic attenuation spectroscopy, inverse scattering problem

\section{1. まえがき}

上流域で生産された土砂は洪水によって河道を流 下して貯水池に堆積する. 貯水池の堆砂は貯水容量 の減少, 貯水池上流部の河床や洪水位の上昇などの 局地的な問題だけでなく，流砂系全体に影響を及ぼ 寸. しかし, 貯水池の堆砂を恒久的に排除寸ること は困難が多く, 近年では土砂が貯水池に堆積するの を防止するため水位低下による土砂スルーシングが 各水系で実施されている.

黒部川の宇奈月, 出し平ダムでは毎年連携排砂が 行われている.これらのダムは本格的な排砂設備を 有するが，既設ダムの多くは本格的な排砂設備を持 たないため，耳川1)ではダムの改造が計画されてい る. 洪水時に水位低下による土砂スルーシングを実 施する場合は, 土砂と水質のモニタリングが重要と なる. 土砂のモニタリングでは SS 濃度と粒度分布
の測定が行われる. SS 濃度の測定は環境庁告示第 59 号付表 9 , 粒度分布は一般的にレーザ回折・散乱 式粒度分布測定装置による方法が用いられる。近年, 流砂系の総合的な土砂管理のため土砂のモニタリン グが行われており，採水分析に代わる測定技術につ いて多くの研究が行われてきた。例えば，角ら ${ }^{2} は$ 黒部川のダム連携排砂による数万 $\mathrm{mg} / \mathrm{l}$ の高濃度 $\mathrm{SS}$ を測定するため, 差圧式 SS 計を開発して連続観測 を行っている. 水垣ら ${ }^{3}$ は $10000 \mathrm{mg} / \ell$ 以上の鵡 川・沙流川の SS 濃度と濁度の観測結果から, 濁度 と流量データを用いた SS 濃度の推定式を提案して いる。 また，古川ら ${ }^{4-9}$ は超音波減衰スペクトル計を 用いた SS 濃度測定技術の開発を進めており, 室内 実験 5) では最大 $50000 \mathrm{mg} / \ell$, 六角川6),9)では $5000 \mathrm{mg} / \ell$ の高濃度 SS 濃度を測定している.

超音波減衰スペクトル計は SS 濃度だけではなく SS の粒度分布を同時にしかも連続して測定できる. 
超音波減衰スペクトル計で測定できる粒径は10 nm 〜3 mm とされている ${ }^{10)}$. しかし六角川の SS は50\% 粒径が $10 \mu \mathrm{m}$ 程度で粒度分布に大きな変動がなく, 超音波減衰スペクトル計による粒度分布の測定性能 を十分検証できなかった。本研究では, 超音波減衰 スペクトル計開発の目的の一つである水位低下によ る土砂スルーシング時の粒度分布と SS 濃度の連続 測定を行い，超音波減衰スペクトル計による粒度分 布と SS 濃度の測定技術を検証した。

\section{2. 測定方法}

SS の測定方法は，(1)超音波減衰スペクトル計（JPOWER-2011モデル，北斗理研株式会社製），(2)光 学式濁度計（後方散乱光方式，カオリン検定，同）, (3)採水による河川水の分析を用いた。 図-1に超音波 減衰スペクトル計と光学式濁度計による測定システ ムの概要を示す. 超音波減衰スペクトル計のプロー ブ, 水温計, 光学式濁度計は本体カプセルの底部に 固定し, 本体カプセルは手動ウインチを用いて陸上 からワイヤーロープで水深 $1.0 \mathrm{~m}$ まで吊り下げた. 測定地点は長野県下伊那郡天龍村に位置する平岡ダ

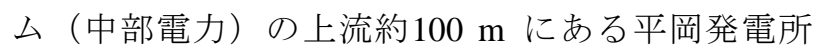
(同) 取水口である. 平岡ダムは天竜川水系天竜川 の中流域にあり, 平岡ダムから約35 km 下流に佐久 間ダムが位置する。測定期間は平成26年10月5日か ら7日までの3日間，10月5日14時からダム放流が開 始された。この出水の最大流入量は約 $1100 \mathrm{~m}^{3} \cdot \mathrm{s}^{-1}$ であった。図-2に平岡ダムの貯水位と流量の経時変 化を, 写真-1に出水時の状況を示す. また, 採水し た河川水の分析項目を表-1に示す.

\section{3. 超音波減衰スペクトル計による SS 濃度と粒度 分布の測定方法}

\section{（1）超音波減衰スペクトル法}

超音波減衰スペクトル法10)は，ECAH 理論11),12)に 基づく周波数と粒子径に依存する超音波の減衰特性 を利用して懸濁液中の微粒子の粒度と濃度を測定す る技術である。減衰スペクトルとは周波数の関数と して測定した減衰係数をいう ${ }^{10)}$. 超音波減衰スペク トル法では逆解析法が用いられる。逆解析法は, 固 体体積分率 $\phi$ と粒度分布モデルを仮定して減衰スペ クトルの推定值を算出し，この推定值と測定值の偏 差の分散 $\sigma^{2}$ が最小となる固体体積分率と粒度分布モ デルを繰り返し計算によって決定する方法で, 次式 が用いられる7),8),9).

$$
\sigma^{2}=\frac{1}{m} \sum_{j=1}^{m}\left[\alpha_{\text {meas }}(f)-\alpha_{\text {mod }}(f)\right]^{2}
$$

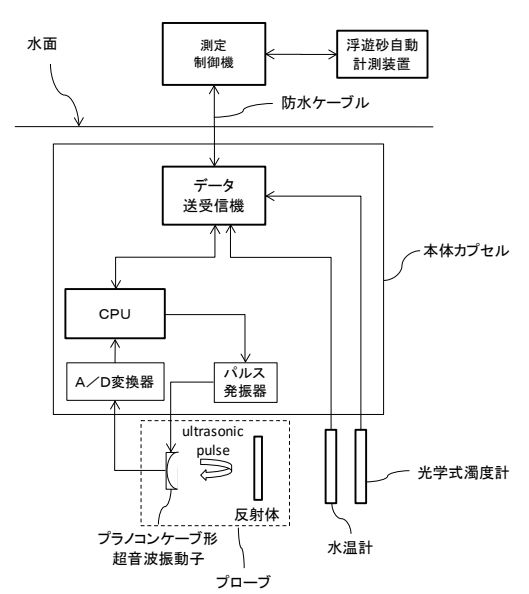

図-1 超音波減衰スペクトル計と光学式濁度計による測定 システムの概要

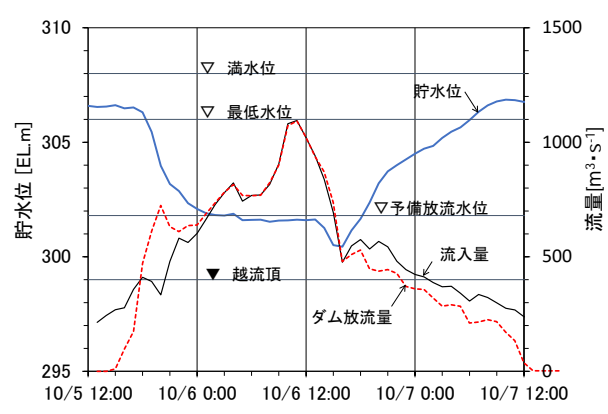

図-2 出水時のハイドログラフ

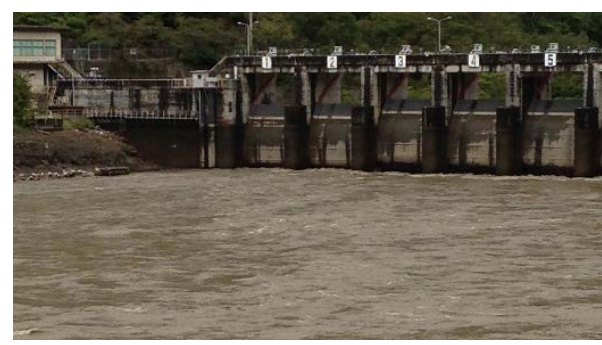

写真 -1 出水時の状況（10月 6 日 12 時）

表-1 採水による河川水の分析

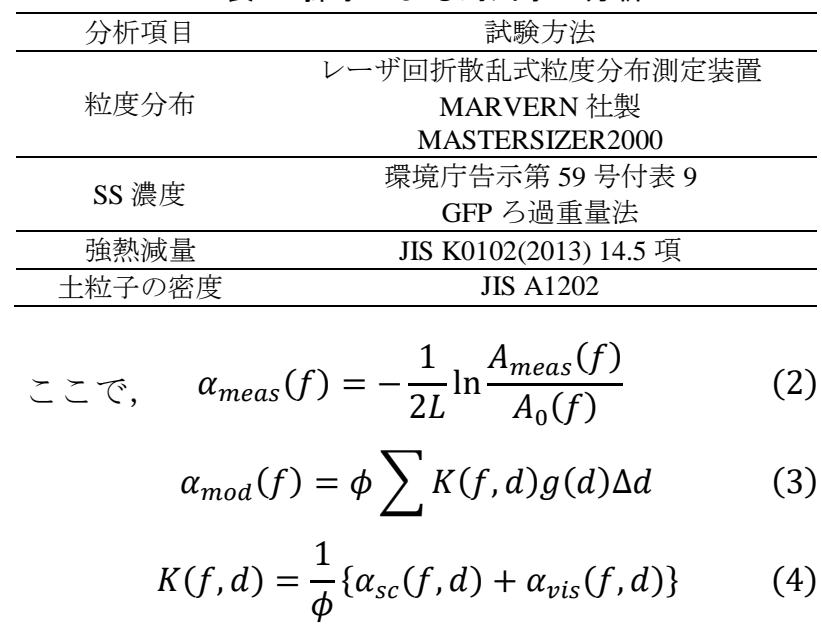

$\alpha_{\text {meas }}(f)$ は周波数 $f$ における減衰係数の測定值, $\alpha_{\text {mod }}(f)$ は周波数 $f$ における減衰係数の推定值, $m$ は測定に用いる周波数の数を示す. 式(2)の $L$ は振動 
子と反射体との間の距離, $A_{0}(f)$ は基準スペクトル の振幅, $A_{\text {meas }}(f)$ は測定したスペクトルの振幅を示 す. 基準スペクトルは, 微粒子を全く含まない水の スペクトルで, 水温, 水の吸収係数および固有音響 インピーダンスからその振幅を算出することができ る $^{13)}$. 式(3)の $K(f, d)$ は周波数 $f$ と粒子径 $d$ に依存す る超音波の減衰特性をモデル化したカーネル行列, $g(d)$ は粒子径 $d$ の粒度分布関数を示す. $\alpha_{s c}(f, d)$ は減衰係数の散乱損失成分, $\alpha_{v i s}(f, d)$ は減衰係数 の粘性損失成分である.

\section{（2）等価球形散乱体モデル}

SSなどの非球形粒子の測定では等価球形散乱体 モデルを用いて減衰係数を算出する. 減衰係数の散 乱損失成分は, Schaafsma and Hay ${ }^{14)}$ が提案した等価 球形散乱体モデルを適用寸る。この実験モデルを次 式に示す。

$$
\begin{aligned}
& \alpha_{s c}(f, d)=-\frac{3 b_{0} \phi}{2 k^{2}\left(a_{0} r\right)^{3}} \sum_{n=0}^{\infty}(2 n+1) \operatorname{Re}\left(A_{n}\right) \\
& \text { ここで, } \quad A_{n}=-\frac{i \cdot \tan \eta_{n}}{1+\tan \eta_{n}}
\end{aligned}
$$

$k$ は波数, $r(=d / 2)$ は粒子の半径, $\operatorname{Re}\left(A_{n}\right)$ は $A_{n}$ の実 部, $A_{n}$ はFaranのn次の散乱係数 ${ }^{15), 16), 17), ~} i=\sqrt{-1}$, $a_{0}$ と $b_{0}$ は Schaafsma の等価粒径係数である. Schaafsma and Hayの実験14)によれば0.6 $<a_{0} \leq 1.0$, $1.0 \leq b_{0}<1.8$ の值が示されている. この等価粒径 係数は現地測定データを解析して決定する.

また，減衰係数の粘性損失成分は次式に示寸古川 $ら^{8), 99}$ の提案した等価球形散乱体モデルを適用する. このモデルはMcClements ${ }^{18)}$ の式に等価粒径係数を導 入した実験モデルである.

$$
\begin{gathered}
\alpha_{v i s}(f, d)=\frac{1}{2} \frac{\phi k s\left(\rho_{2}-\rho_{1}\right)^{2}}{\left(\rho_{2}+T \rho_{1}\right)^{2}+s^{2} \rho_{1}^{2}} \\
\text { ここで, } \quad s=\frac{9 \delta_{v}}{4 c_{0} r}\left(1+\frac{\delta_{v}}{c_{0} r}\right) \\
T=\frac{1}{2}+\frac{9 \delta_{v}}{4 c_{0} r}
\end{gathered}
$$

$\rho_{1}$ は水の密度, $\rho_{2}$ は粒子の密度, $\delta_{v}=\sqrt{2 \eta_{1} / \omega \rho_{1}}$, $\eta_{1}$ は水の粘度, $\omega(=2 \pi f)$ は角周波数, $c_{0}$ は粘性損 失の等価粒径係数で, 古川らの実験 ${ }^{9}$ によれば $c_{0} \leq$ 1.0 である. この等価粒径係数も現地測定データを 解析して決定する.

\section{(3) 粒度分布関数}

式(3)に適用寸る粒度分布関数は二峰性対数正規 分布 (Bimodal log-normal distribution，以下「BLN」 という）モデルを用いる．BLNモデルは，
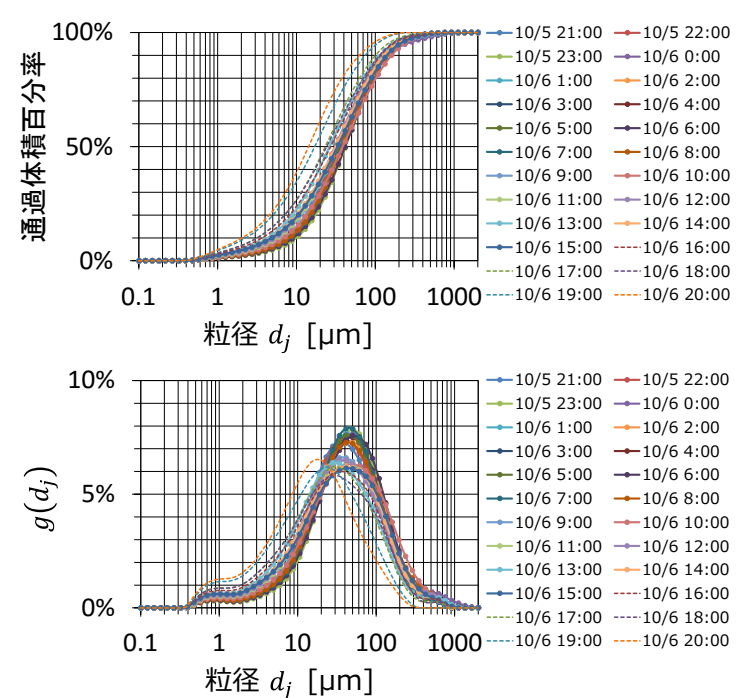

図-3 土砂スルーシング時の SS の粒度分布（50 粒径）
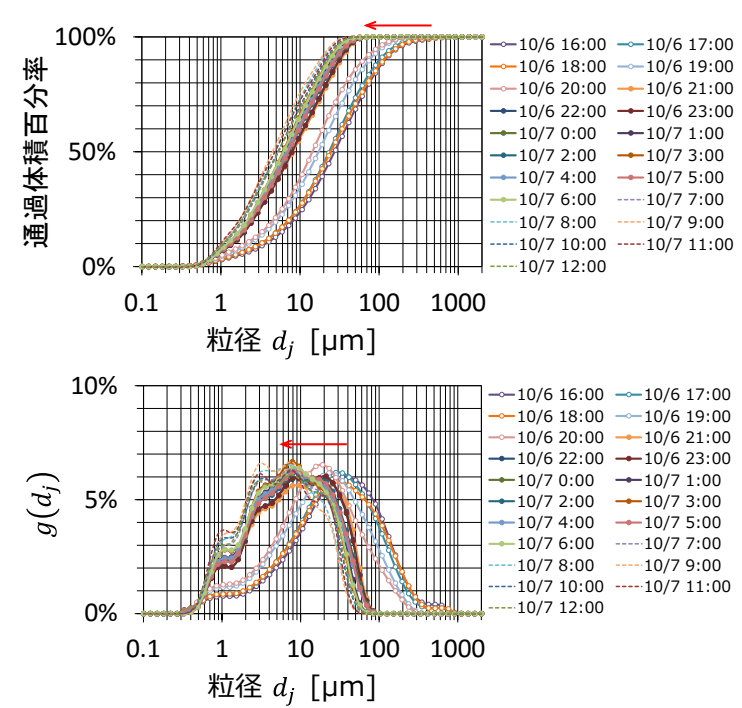

図-4 水位回復時の SS 粒度分布 (50 粒径)

$$
\begin{gathered}
g\left(d_{j}\right)=p_{1} g_{1}\left(d_{j}\right)+\left(1-p_{1}\right) g_{2}\left(d_{j}\right) \\
\text { ここで, } \quad g_{N}\left(d_{j}\right)=\frac{1}{\sqrt{2 \pi} \sigma_{N}} \exp \left[-\frac{\left(x_{j}-\mu_{N}\right)^{2}}{2 \sigma_{N}{ }^{2}}\right] \\
x_{j}=\ln d_{j} \\
\mu_{N}=\ln \bar{d}_{N}
\end{gathered}
$$

$g\left(d_{j}\right)$ は粒子径 $d_{j}$ の頻度, $g_{N}\left(d_{j}\right)$ は粒度分布 $N$ の粒子 径 $d_{j}$ の頻度, $d_{j}$ は粒径階級 $j$ の粒子の粒子径, $\bar{d}_{N}$ は 粒度分布 $N$ の平均粒子径, $\sigma_{N}$ は粒度分布 $N$ の標準偏 差, $N=1,2, p_{1}$ は比率である.

\section{4. 等価球形散乱体モデルの適用}

\section{（1）粒度分布コード}

土砂スルーシング時（10月5日21時〜10月6日20時） のSSの粒度分布の測定結果を図-3に示す，粒径区 分は $0.1 \mu \mathrm{m} \sim 2 \mathrm{~mm}$ の0粒径である. 図-3に示すよう 
表-2 粒度分布コード（土砂スルーシング時）

\begin{tabular}{rlrlllll}
\hline No. & \multicolumn{1}{l}{ 測定日 } & \multicolumn{1}{l}{ 時 } & \multicolumn{1}{l}{$p_{1}$} & \multicolumn{1}{l}{$\mu_{1}$} & \multicolumn{1}{l}{$\sigma_{1}$} & $\mu_{2}$ & $\sigma_{2}$ \\
\hline 1 & $2014 / 10 / 5$ & 21 & 0.18 & 2.71 & 1.80 & 3.58 & 0.95 \\
2 & $2014 / 10 / 5$ & 22 & 0.22 & 2.86 & 1.80 & 3.63 & 0.90 \\
3 & $2014 / 10 / 5$ & 23 & 0.24 & 3.14 & 1.75 & 3.83 & 0.85 \\
4 & $2014 / 10 / 6$ & 0 & 0.28 & 3.39 & 1.95 & 3.72 & 0.85 \\
5 & $2014 / 10 / 6$ & 1 & 0.26 & 3.00 & 1.75 & 3.70 & 0.85 \\
6 & $2014 / 10 / 6$ & 2 & 0.18 & 2.74 & 1.80 & 3.77 & 0.95 \\
7 & $2014 / 10 / 6$ & 3 & 0.18 & 2.58 & 1.80 & 3.70 & 0.90 \\
8 & $2014 / 10 / 6$ & 4 & 0.20 & 2.67 & 1.80 & 3.73 & 0.90 \\
9 & $2014 / 10 / 6$ & 5 & 0.16 & 2.09 & 1.40 & 3.73 & 0.90 \\
10 & $2014 / 10 / 6$ & 6 & 0.16 & 2.30 & 1.45 & 3.87 & 0.90 \\
11 & $2014 / 10 / 6$ & 7 & 0.22 & 3.62 & 1.75 & 3.71 & 0.85 \\
12 & $2014 / 10 / 6$ & 8 & 0.18 & 2.69 & 1.85 & 3.74 & 0.95 \\
13 & $2014 / 10 / 6$ & 9 & 0.26 & 2.72 & 1.80 & 3.63 & 1.00 \\
14 & $2014 / 10 / 6$ & 10 & 0.18 & 2.22 & 1.50 & 3.85 & 1.05 \\
15 & $2014 / 10 / 6$ & 11 & 0.18 & 2.03 & 1.50 & 3.68 & 1.05 \\
16 & $2014 / 10 / 6$ & 12 & 0.28 & 2.56 & 1.70 & 3.63 & 1.00 \\
17 & $2014 / 10 / 6$ & 13 & 0.34 & 2.61 & 1.70 & 3.47 & 1.00 \\
18 & $2014 / 10 / 6$ & 14 & 0.28 & 2.20 & 1.45 & 3.75 & 1.00 \\
19 & $2014 / 10 / 6$ & 15 & 0.28 & 2.22 & 1.55 & 3.80 & 1.00 \\
20 & $2014 / 10 / 6$ & 16 & 0.32 & 2.10 & 1.50 & 3.66 & 1.00 \\
21 & $2014 / 10 / 6$ & 17 & 0.30 & 1.85 & 1.45 & 3.50 & 1.00 \\
22 & $2014 / 10 / 6$ & 18 & 0.24 & 1.51 & 1.30 & 3.55 & 1.05 \\
23 & $2014 / 10 / 6$ & 19 & 0.36 & 1.63 & 1.30 & 3.30 & 0.95 \\
24 & $2014 / 10 / 6$ & 20 & 0.22 & 1.02 & 1.15 & 2.97 & 1.00 \\
\hline
\end{tabular}

表-3 等価粒径係数の解析データ

\begin{tabular}{|c|c|c|}
\hline \multicolumn{2}{|c|}{ 測定日時 } & 2014/10/06_5:00 \\
\hline SS 濃度 & $C$ & $0.457 \mathrm{~kg} \cdot \mathrm{m}^{-3}$ \\
\hline 土粒子密度 & $\rho_{2}$ & $2645 \mathrm{~kg} \cdot \mathrm{m}^{-3}$ \\
\hline 固体体積分率 & $\phi_{\text {meas }}\left(=C / \rho_{2}\right)$ & $173 \times 10^{-6}$ \\
\hline 粒度分布 & $g(d)$ & 粒度分布コード No.9 \\
\hline
\end{tabular}

表-4 等価粒径係数の解析条件

\begin{tabular}{cccc}
\hline 係数 & 最小值 & 最大值 & 計算間隔 \\
\hline$a_{0}$ & 0.50 & 1.00 & 0.01 \\
$b_{0}$ & 1.00 & 1.80 & 0.01 \\
$c_{0}$ & 0.40 & 1.00 & 0.01 \\
$\phi\left[\times 10^{-6}\right]$ & 1 & 500 & 1 \\
\hline
\end{tabular}

表-5 等価粒径係数の解析結果

\begin{tabular}{ccccc}
\hline$a_{0}$ & $b_{0}$ & $c_{0}$ & $\phi\left[\times 10^{-6}\right]$ & $\varepsilon\left(=\phi_{\text {meas }} / \phi\right)$ \\
\hline 0.97 & 1.04 & 0.55 & 312 & 0.554 \\
\hline
\end{tabular}

に10月5日21時から6日15時までのSSの50\%粒径は約 $40 \mu \mathrm{m}$ で粒径 $100 \mu \mathrm{m}$ 以上の細砂が約20\%含まれてい る.この期間中は平岡ダムに600 1 $100 \mathrm{~m}^{3} \cdot \mathrm{s}^{-1}$ の 流入量があり，写真-1に見られるよう貯水位が最低 水位から大きく低下した状態で貯水池は河川状態と なる.このため上流から流入する土砂の多くは貯水 池に堆積することなくダムを通過したと考えられる。 また, 図-4は水位回復時の粒度分布の測定結果を示 す. 流入量の減少にともない水位回復が行われる. 図-4に示すよう水位回復期間のSSの50\%粒径は約 $30 \mu \mathrm{m}$ から $5 \mu \mathrm{m}$ 程度まで大きく変化していることが 分かった。土砂スルーシング時の粒度分布をBLNモ デルで近似した結果を表-2に示す。表-2に示すBLN モデルの5個の係数を粒度分布コード9)と呼んでいる. この粒度分布コードを超音波減衰スペクトル計によ るSS濃度と粒度分布の測定に用いた。

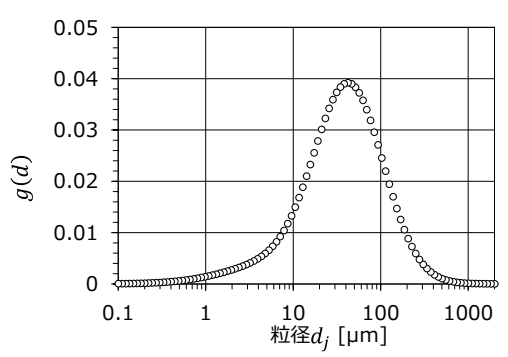

図－5 粒度分布コード（No. 9） から算出した BLN 粒度分 布モデル (100 粒径)

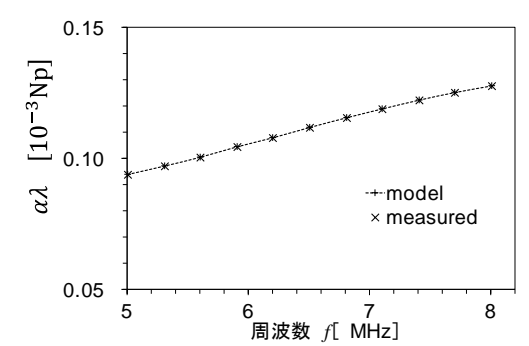

図-6 等価粒径係数を決定した減衰スペクトルの測定値と 推定值のベストフィット

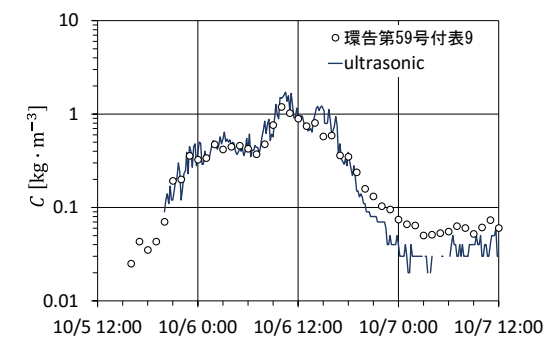

図-7 超音波減衰スペクトル計による SS 濃度測定結果

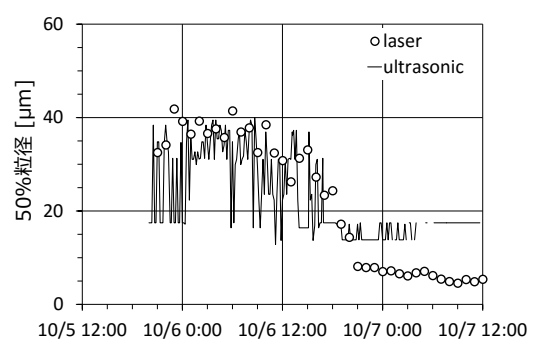

図-8 超音波減衰スペクトル計による SS 粒度分布の測定 結果 (50\%粒径)

\section{(2) 等価粒径係数}

等価球形散乱体モデルに適用する等価粒径係数は 古川らが提案した方法9)用いて決定した。この方 法は SS 濃度と粒度分布の測定值を式(1)に適用して 減衰スペクトルの測定值と推定值がベストフィット する等価粒径係数を決定する方法である。測定值は 式(2), 推定值は式(3)加算出し, 粒度分布 $g(d)$ は BLN モデルを用いる. 等価粒径係数の解析データ を表-3, 解析条件を表-4, 解析結果を表-5に示す. 等価粒径係数は $a_{0}=0.97, b_{0}=1.04, c_{0}=0.55$, $\varepsilon=0.554$ はVSS 補正係数9)である. 解析に用いた BLN 粒度分布モデルを図-5に, また減衰スペクト 


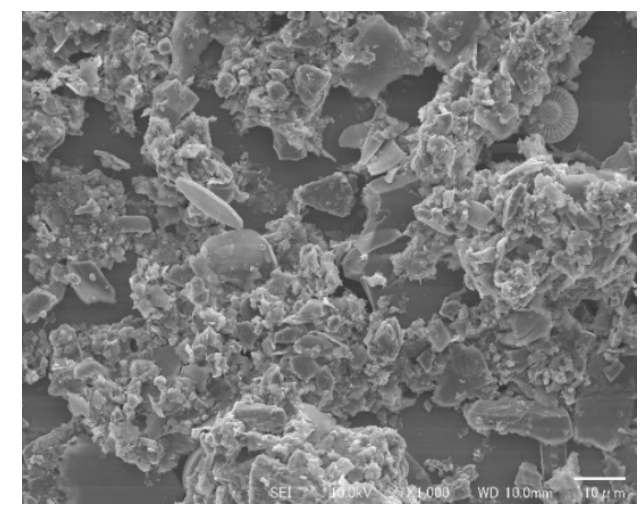

写真-2 浮遊物質の団粒構造（10月 6 日 0 時採水）

ルの測定值と推定值がベストフィットした結果を図 -6に示す. 図-6の縦軸は減衰係数 $\alpha$ と超音波の波長 $\lambda(=c / f)$ との積, $c$ は超音波の音速を示す9).

\section{（3）等価球形散乱体モデルによる SS 濃度と SS 粒} 度分布の測定結果

等価球形散乱体モデルに表-5に示寸等価粒径係数 $a_{0}, b_{0}, c_{0}$ とVSS補正係数 $\varepsilon$ を適用して粒度分布とSS 濃度を測定した。粒度分布 $g(d)$ はBLNモデルを適用 し, 表-2に示す土砂スルーシング時の粒度分布コー ドを用いた。 SS濃度 $C$ は次式で算出した。

$$
C=\varepsilon \cdot \rho_{2} \cdot \phi
$$

ここで， $\phi$ は式(1)から求めた固体体積分率である。 図-7に超音波減衰スペクトル計による SS 濃度の測 定值（ultrasonic）と採水して環告第59号付表9に基 づき測定した SS 濃度の経時変化を示す. 超音波減 衰スペクトル計による測定值と環告第59号付表 9 に よる測定值は, SS 濃度が $0.1 \mathrm{~kg} \cdot \mathrm{m}^{-3}$ 以上ではよく 一致するが，これより低濃度の領域では測定誤差が やや大きくなる傾向がみられた。また, SS 粒度分 布の測定結果を図-8に示寸。10月5日21時から6日15 時までの超音波減衰スペクトル計による50\%粒径の 測定值 (ultrasonic) は，採水してレーザ回折・散乱 式粒度分布測定装置を用いて測定した $50 \%$ 粒径 (laser) とほぼ一致することが分かった。しかし， 一部にレーザによる測定值と一致しない超音波減衰 スペクトル計の測定值が見られた。この原因は，本 体カプセルを水中に吊り下げた状態で測定したため, 本体カプセルに取付けたプローブを固定した状態で 測定できなかったことによるものと考えられる.

\section{5. 考察}

\section{(1) 等価粒径係数}

等価粒径係数 $a_{0}, c_{0}$ は不規則な形状をもつ粒子の 粒径を超音波減衰特性の等しい球形粒子の粒径に換

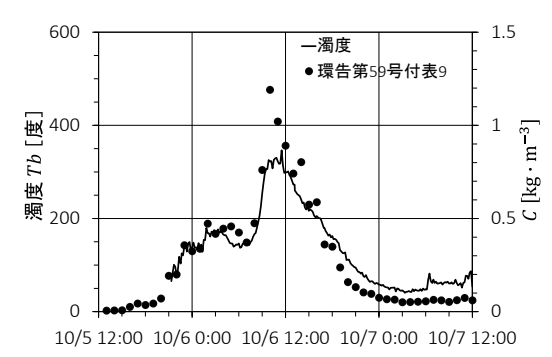

図-9 濁度と SS 濃度の測定結果

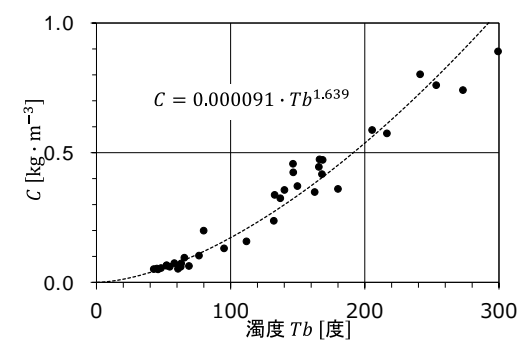

図-10 濁度と SS 濃度との関係

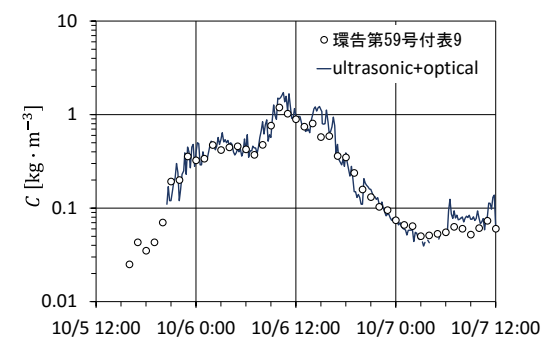

図-11 超音波減衰スペクトル計と光学式濁度計による SS 濃度の測定結果

算する係数， $b_{0}$ は濃度補正係数である.これらの 係数の導入によって ECAH 理論に基づく線形モデル を適用することができる。古川ら ${ }^{8)}$ が実施した天竜 川産の不規則な粒子形状をもつシルトや細砂の実験 によれば， $a_{0}=0.68, b_{0}=1.54$ が得られている.

表-5に示寸平岡ダム地点の粒径係数は, $a_{0}=0.97$, $b_{0}=1.04$ であり, 同じ天竜川産のシルト・細砂の 測定において等価粒径係数に相違が見られた。この 原因を調查するためSEM を用いて SS 粒子の形状を 観察した結果を写真-2に示寸. SS は，(1)単粒構造 ではなく粒径の異なる粒子の団粒構造であること， (2)珪藻等の有機物が含まれていることが明らかに なった。この時の強熱減量は約 $10 \%$ \%った．等価 粒径係数が 1.0 に近い值を示寸要因は粒子の構造が 単粒構造ではなく団粒構造であるためと考えられる。

\section{（2）モデル依存の逆解析による粒度分布の測定}

超音波減衰スペクトル法による粒度分布の測定に は粒度分布モデルを用いた逆解析が用いられる。 BLN モデルは5個の係数で粒度分布を表すことがで き，しかもSS の粒度分布を実用的な精度で表現で きるモデルである．しかし，BLN モデルの5個の係 
数には無数の組み合わせがあり, また，実際の粒度 分布と大きく異なるモデルを用いても減衰スペクト ルの推定值が測定值とベストフィットする場合があ る.このため, 本論では土砂スルーシング時の粒度 分布の測定結果を BLN モデルで近似して逆解析に 適用することによって粒度分布・SS 濃度ともに精 度の良い測定結果が得られた。

\section{（3）超音波減衰スペクトル計と光学式濁度計によ}

\section{るSS 濃度の測定システム}

光学式濁度計の測定值（濁度）とSS濃度の経時 変化を図-9 に示す. また濁度と環境庁告示第 59 号 付表 9 に基づくSS濃度との関係を図-10 に示す. SS 濃度 $C$ は濁度 $T_{b}$ を用いて次式から算出できる。

$$
C=0.000091 \times T_{b}{ }^{1.639}
$$

図-11 に超音波減衰スペクトル計と光学式濁度計に よるSS濃度の測定結果を示す。濁度が 100 度以下 の場合は式(15)を用いて濁度からSS濃度を算定した。 図-7 と図-11 を比較すると, 超音波減衰スペクトル と光学式濁度計を併用した測定システムによるSS 濃度の測定值は, 超音波減衰スペクトルの測定值よ り, 環境庁告示第 59 号付表 9 に基づくSS濃度と一 致することがわかる。このシステムの採用によって 出水時の全期間を通して測定精度の高いSS濃度の 連続測定が可能となる.

\section{6. 結論}

本論では水位低下による土砂スルーシング時の粒 度分布とSSの濃度を測定し, 超音波減衰スペクト ル法による測定技術を検証した。本論で得られた結 論は以下のとおりである.

1) 等価球形散乱体モデルとBLN粒度分布モデルを 用いて時間とともに変化するSSの粒度分布と濃 度を同時に連続して測定できることが分かった。

2) 等価粒径係数は, 粒子の形状だけでなく粒子の 構造（単粒, 団粒）にも依存することが示唆さ れた.

3）超音波減衰スペクトル計と光学式濁度計を併用 した測定システムの採用によって出水時の全期 間を通した測定精度の高いSS濃度の連続計測が 可能となる.

謝辞 : 本研究は中部電力株式会社長野支店飯田電力 センター平岡ダム管理所のご協力を得て実施した. ここに記して謝意を表する.

\section{参考文献}

1) 吉武宏晃, 吉村健, 三谷泰裕 : 耳川水系ダム通砂にお ける土砂管理にための貯水池への流入土砂量把握に関
する研究, 電力土木, No.373, pp.28-32, 2014.

2) 角哲也, 森田佐一郎, 小宮秀昭: 水中型SMDPを用い た黒部川ダム排砂時の高浮遊砂濃度連続計測, 水工学 論文集，第54巻，pp.1111-1116，2010.

3) 水垣滋, 阿部孝章, 丸山政浩 : 濁度計による高濃度濁 水中の浮遊土砂濃度推定法, 寒地土木研究所月報, No.706, 2012.

4) Tsutomu Kobayashi et al. : Measurement method of particle concentration and acoustic properties in suspension using a focused ultrasonic impulse radiated from a planoconcave transducer, Ultrasonics 44, e491-e496, 2006.

5) 古川仁志, 猪股重光, 田井秀一, 小林力 : 超音波減衰 スペクトル法を用いた流水中の浮遊砂濃度と粒度分布 の計測技術に関する研究, 河川技術論文集, 第19巻, pp.129-134, 2013.

6) 古川仁志，猪股重光，田井秀一，小林力：超音波減衰 スペクトル法による六角川感潮部の矁濁物質濃度と粒 度分布の連続計測, 土木学会論文集B1（水工学）, 第 70巻, No.4, pp.I_607-612,2014.

7) 古川仁志, 猪股重光, 田井秀一, 小林力 : 流水中の浮 遊物質の連続計測に用いる超音波減衰スペクトル法の 二種類の線形理論, 河川技術論文集, 第20巻, pp.1-6, 2014.

8) 古川仁志, 猪股重光, 田井秀一, 小林力 : 流水中の浮 遊土砂の粒子形状が超音波減衰スペクトルに及ぼす影 響, 水工学論文集, 第59巻, 2015.

9）古川仁志，猪股重光，田井秀一，小林力：超音波減衰 スペクトル計によるSS測定に用いる等価球形散乱体 モデルの検証，河川技術論文集，第21巻，pp.55-60， 2015.

10) ISO 20998-1 : Measurement and characterization of particles by acoustic methods - Part 1: Concepts and procedures in ultrasonic attenuation spectroscopy, 2006.

11) P. S. Epstein and R. R. Carhart : The Absorption of Sound in Suspensions and Emulsions, J. Acoust. Soc. Am. 25, pp.553-565, 1953.

12) J. R. Allegra and S. A. Hawley : Attenuation of Sound in Suspensions and Emulsions - Theory and Experiments, J. Acoust. Soc. Am. 51, pp.1545-1564, 1972.

13) 古川仁志, 猪股重光, 田井秀一, 小林力 : パスレング スを固定した超音波減衰スペクトル計の海水中の固有 周波数応答, 日本音響学会講演論文集, pp.1115-1118, 2015.

14) S. Schaafsma and A. E. Hay : Attenuation in suspensions of irregularly shaped sediment particles : A two-parameter equivalent spherical scatterer model, J. Acoust. Soc. Am 102(3), pp.1485-1502, 1996.

15) J. J. Faran Jr. : Sound scattering by Solid Cylinders and Spheres, J. Acoust. Soc. Am 23(4), pp.405-418, 1951.

16) A. Richter, F. Babric, and S. Ripperger : Polydisperse particle size characterization by ultrasonic attenuation spectroscopy for systems of diverse acoustic contrast in the large particle limit, J. Acoust. Am. 118 (3), 2005.

17) E. Hay and D. G. Mercer : On the theory of sound scattering and viscous absorption in aqueous suspensions at medium and short wavelengths, J. Acoust. Soc. Am. 78(5), pp.17611771, 1985.

18) D. J. McClements, J. N. Coupland : Theory of droplet size distribution measurement in emulsions using ultrasonic spectroscopy, Colloids and surfaces A:Physicochemical and Engineering Aspect 117 ,pp.161-170,1996

(2015. 9. 30 受付) 